\title{
Allegorising Song of Song's Most Erotic Parts: Judaism, Calvinism, Lutheranism
}

\author{
EBEN SCHEFFLER (UNIVERSITY OF SOUTH AFRICA)
}

\begin{abstract}
The contemporary debate regarding the neo-allegorical Song of Songs interpretation focuses more on its legitimacy than on how it is done. If allegorical interpretation promotes uncontrollable subjective interpretation, this would especially surface when different religious traditions are involved. Moreover, if allegorical interpretation is done to avoid dealing with explicit sexuality in the Song, comparing texts from three diverse religious traditions on the more erotic parts of the Song has the potential to provide insight not only in the method of allegory but also in the contextuality and subjectivity of interpretation as such. The paper discusses examples from the Targum, the Calvinistic Dutch Statenbijbel and Luther's lectures on the Canticles.
\end{abstract}

KEYWORDS: Song of songs, erotic, allegorism, Judaism, Calvinism, Lutheranism

\section{A. INTRODUCTION}

The neo-allegorical interpretation of Song of Songs was already foreshadowed in the 1998 version of Zenger's Einleitung in das Alte Testament ${ }^{1}$ by Schwienhorst-Schönenberger and strongly argued by him during the 2014 Vienna conferences (Song of Songs Seminar as well as SBL). His view is also reflected in his short commentary on Song of Songs. ${ }^{2}$ It will be my contention that one should concede to Schwienhorst-Schönenberger that he does not deny the sexuality of the Song of Songs (henceforth SoS). On the other hand, it should be acknowledged that the results of an allegorical interpretation do not lie implicit in the text, since anything (even opposite views) can be proved with the latter. Allegorical interpretations (which can be very creative and artistic) do exist and must therefore be recognised in their own right. However, these

\footnotetext{
* Submitted: 05/11/2018; peer-reviewed: 27/11/2018; accepted: 14/12/2018. Eben Scheffler "Allegorising Song of Song's Most Erotic Parts: Judaism, Calvinism, Lutheranism," Old Testament Essays 31 no. 3 (2018): 737-758. https://doi.org/10. 17159/2312-3621/2018/v31n3a19.

1 Zenger, E. et al. (eds.). Einleitung in das Alte Testament (3rd ed.; Stuttgart: Kohlhammer, 1998), 351.

2 Schwienhorst-Schönenberger, L. Das Hohelied der Liebe (Freiburg: Herder, 2015); see also Zenger et al. Einleitung in das Alte Testament. (9th updated ed.; Stuttgart: Kohlhammer, 2016), 487.
} 
interpretations function on the level of hermeneutics and therefore always remains interpretation and not exegesis.

In what follows, I will pursue allegorical interpretation by comparing the Targum on SoS $(2018)^{3}$, Luther's lectures on $\mathrm{SoS}^{4}$ and the Dutch Statenbijbel ${ }^{5}$ in order to gain more insight into their creativity and contextuality. Moreover, the purpose is also to gain insight into the contextuality of interpretation and exegesis as such.

In this contribution, attention will be paid to the most erotic parts (pun intended) of SoS. This is due to the fact that it is often alleged that SoS has been, since the time of Rabbi Akiba, ${ }^{6}$ interpreted allegorically in order to avoid its explicit sexuality. Assuming that the pericopes in which eroticism appear have been sufficiently exegetised (in a modern sense, indicating their erotic connotations) elsewhere, some 20 texts will be considered, which most modern commentators ${ }^{7}$ consider as being unmistakenly erotic. But immediately one should take into account what Holman ${ }^{8}$ argues, namely that the erotic parts of the Song also appear in veiled or metaphoric language and are dependent on the

3 The Targum to Song of Songs is available in both European and Yemenite manuscripts. The Aramaic text used in this translation is that of Melamed 1919-1922. The translation by Jay C. Treat began as an adaptation of the translations by Pope 1977. For the purposes of this contribution and constraints of space the discussions will be limited to English translations. As for the Statenbijbel, relevant translations into English have been done by me.

4 Martin Luther, Notes on Ecclesiastes. Lectures on the Song of Solomon. Treatise on the last words of David (ed. By Jaroslav Pelikan; Luther's Works Vol. 15; Saint Louis: Concordia Publishing, [1539] 1972), 190-264.

5 Statenbijbel 1637:643-663.

6 According to Akiba, the youth of his day would impiously relish a literal interpretation.

7 E.g. W. Rudolph, Das Buch Ruth, Das Hohelied, Die Klagelieder (KAT 17. Gütersloh: Gerd Mohn, 1962); G. Gerleman, Ruth, Das Hohelied (Neukirchen: Neukirchener Verlag. 1965); Marvin H. Pope, Song of Songs: A New Translation and Commentary (The Anchor Bible 7C; New York: Doubleday \& Company, 1977); H. Ringgren, 'Das Hohelied' in Das Hohelied/Klagelieder/Das Buch Ester (eds. Ringgren, H. \& Kaiser, O.; 3rd ed.; ATD 16/2; Göttingen: Vandenhoeck \& Ruprecht, 1981), 253292. Müller, H.-P.. "Das Hohelied," in Das Hohelied/Klagelieder/Das Buch (eds. Ester H.-P. Müller, O. Kaiser, \& J.A. Loader; 4th ed.; ATD 16/2; Göttingen: Vandenhoeck \& Ruprecht, 1992), 1-90; O. Keel, The Song of Songs: a continental commentary (Trans. by F.J. Gaiser; Minneapolis: Fortress Press, 1994); D Carr, The erotic word: Sexuality, Spirituality and the Bible (Oxford: Oxford University Press, 2003); S Fischer, Das Hohelied Salomos zwischen Poesie und Erzählung (Tübingen: Mohr Siebeck, 2010); F. Landy, Paradoxes of paradise: Identity and difference in the Song of Songs (2nd ed.; Sheffield: Sheffield Phoenix Press, 2011).

8 Jan Holman, "Pleidooi voor een onderaards Hooglied: Resultaten van een cultureel-antropologische lazing," Tijdschrift voor Theologie 37 (1997):113-131. 
eye of the beholder. According to Holman, many parts of the Song can be likened to a three-story house, first the erotic, second the literal, and thirdly a spiritual interpretation (reminding one of the distinctions made by the Antiochian school of exegesis in the early church). If his theory resolves the debate around SoS's allegorical versus erotic interpretation is an open question.

\section{B. THE TARGUM, LUTHER AND THE STATENBIJBEL ON TWENTY EROTIC REFERENCES IN SONG OF SONGS}

\section{Repeated and passionate kissing (1.2)}

The eroticism of SoS is not confined to sections where breasts or genitalia are mentioned or implied. Exum is right that with the opening verses ('Let him kiss me with the kisses of his mouth for your caresses are better that wine,') 'desire bursts suddenly and dramatically onto the scene' ${ }^{9}$. According to Pope ${ }^{10}$ the kisses are undoubtedly the lovers deep (French?) kisses.

The Targum renders 1.2 as follows:

Solomon the prophet said: 'Blessed be the name of YY who gave us the Torah by the hand of Moses the great scribe, inscribed on two tablets of stone, and [gave us] six orders of the Mishnah and the Gemara by oral tradition, and conversed with us face to face (as a man who kisses his companion) out of the great love with which $\mathrm{He}$ cherished us, more than the seventy nations.'

The Targum is actually not a direct translation but a version in which the Hebrew text is interpreted ${ }^{11}$. Therefore, it is comparable to commentaries like that of Luther or the Statenbijbel. As can be seen above the kisses are related to the giving of the Law and the latter's later interpretations (Mishna, Talmud) and therefore anachronistic. However, the idea of kisses as an expression of love is not absent, but it refers to God's preferential love for Israel.

According to Luther" ${ }^{12}$ 'kisses are signs of love and favour... He shows favour to this government, He kisses it, He honours it with all manner of blessings and love'. The caresses of $2 \mathrm{~b}$ are translated by Luther as breasts (from the LXX and Vulgata) and for him it refers to 'doctrine by which souls are fed'13. The latter is compared to wine for it (the doctrine) gives pleasure.

9 J. C. Exum, Song of Songs: A Commentary (OTL: London: SCM. 2005), 92.

10 Pope, Song of Songs, 297-298.

11 Ibid., 21.

12 Luther, Notes on Ecclesiastes, 196.

13 Ibid. 
Luther reads the Song politically. ${ }^{14}$ God is the male lover, but the human component is the state or government with all its functions and officials. Throughout his commentary, though there is a shift of focus, in the first chapters the focus is on the government of Luther's day, then Solomon's government (quite contextual!) and finally the church (ch 8).

According to the Statenbijbel's commentary ${ }^{15}$, the words of 1.2 are those of the bride, the congregation or church, about the Bridegroom, Jesus Christ. God is not mentioned but implied by Jesus Christ. Kisses refer to Christ's love and the plural especially to the 'richness of his multiple grace'. The mouth refers to the Word of Christ. The dodeka, caresses, refer to the outstanding love and good deeds done to the congregation.

From the outset, one can therefore see that the human component in the Targum is Israel; for Luther, it is the German (Christian) state and for the Statenbijbel, it is the church of Christ. Nowhere is the erotic component denied: in all three interpretations, kisses refer to love, though in the Targum especially the Law.

\section{Taking her in the chambers-to do what? (1.4)}

According to Exum it is clear from v. 4 that the woman and her beloved (which is king to her) delight in one another in his chambers (the motif appears also in the rest of the book). ${ }^{16}$ She is so besotted with him that she imagines all women would be. A harem situation is therefore unlikely. It is left to the reader's imagination that the "delight in one another" implies sexual activity.

The imagination of the Targumist however, went in another direction: being drawn to Mount Sinai to receive the Law. The delight, the rejoicing is not that of two people in one another, but the delight in the Law. The rendering of the Targum is quite creative:

When the people of the House of Israel went out from Egypt, the Presence ${ }^{17}$ of the Lord of the World was their leader; it went before them with a pillar of cloud by day and with a pillar of fire by night. The righteous of that generation said: 'Master of all the World, draw us after you and we will run after the path of your goodness. So draw us near to the base of Mount Sinai and give us your Laws from your treasure house of the Firmament. And we will rejoice and be glad with

14 For a respectable introduction to Luther's thought that serves well as a background for his commentary on Canticles, see H. Küng, Grosse christliche Denker (München: Piper Verlag, 1994), 151-184.

Küng 1994:151-184.

15 Statenbijbel 1637: 653.

16 Exum, Song of Songs, 95-97.

17 Throughout this translation, the word "Presence" translates the word Shekhinah. 
the twenty-two letters with which they are written and we will be mindful of them and will love your divinity and will remove ourselves from the idols of the nations. And all the righteous who do what is upright in your sight will revere you and love your commands.'

As so often Luther does not deny the 'groom bringing his bride into his chamber' (note: not merely lovers), but he uses the intimacy to relate it to prayer and the goodwill of God. ${ }^{18}$ According to Luther, Solomon '... figuratively shows that prayer is heard, for he is picturing God's highest goodwill toward us. "God," he says, "consoles me in the evils I experience in government and reveals Himself to be willing and favourable - just when a groom brings his bride into his chamber, he certainly does not do so from hatred of the bride.' ${ }^{19}$ Luther therefore cannot be suspected of trying to explain away erotic intimacy, but from his political context, eventually conveys another message.

As far as the Statenbijbel is concerned, the imagination also goes elsewhere. ${ }^{20}$ The king refers to Christ and two options are offered for the chambers. Firstly, the mysteries of the kingdom of Christ which was covered in the Old Testament but now fully revealed in the New, or secondly, the kingdom of heaven where there (according to Jn. 14.2) are many chambers. There is no sign that the Statenbijbel tried to avoid sexual intimacy or that it recognised it. It seems that the basic belief in the gospel of Christ is so overriding that the plain meaning of the text is overlooked.

So again, the Jewish text is interpreted in terms of the Law and Israel, the Lutheran in terms of contemporary government and the Calvinistic one in terms of the Christian gospel.

\section{Lying between the women's breasts (1.13)}

In the dialogue between lovers of 1.9-17 the woman utters an almost explicit erotic fantasy:

'My beloved is to me a bag of myrrh that lies between my breasts' (1.13).

It is very difficult to find any traces of myrrh or breasts in the Targum:

At that time YY said to Moses: 'Go; descend, for your people have done wrong. Go away from Me and I will destroy them.' Then Moses turned and begged mercy from YY. And in their favour YY remembered the binding of Isaac, whose father bound him on the altar

18 Luther, Notes on Ecclesiastes.

19 Luther, Notes on Ecclesiastes.

20 Statenbijbel 1637: 653. 
on Mount Moriah. And YY turned from His anger and made his Presence dwell among them as before.

The bag may refer to Isaac's binding which prompted the renewed dwelling of God's presence amongst the people (= lying between the breasts).

What we surmise about the Targum is so stated by Luther who comments:

Now he adds his commendation of the comfort and enlarges on the consolation with images of sweetness. 'God is not far away, but $\mathrm{He}$ dwells in the midst of our life and is like a bag of myrrh in my bosom and in my embraces. That is, He cares for me, protects and comforts me, etc. In short, His feeling for me is like that of a bridegroom for his bride. ${ }^{21}$

Again, Luther recognises the sexual dimension, but restricted to a marriage context which is not necessarily supposed in Song of Songs.

For the Statenbijbel the beloved is Christ who showed his love through his bitter suffering, and the latter fact is cherished between the breasts. ${ }^{22}$ Pope $^{23}$ remarks that women wearing a cross between their breasts take their clue from here. Jalin is not here translated as lie, but "vernacht" (= spend the night). According to Exum ${ }^{24}$ this is a correct translation. The Statenbijbel continues to interpret in terms of "spending the night" that the church should still remember God (her bridegroom), especially through the dark night of persecutions and afflictions, and thereby comforting and strengthening herself.

\section{The fruit of the apple tree that is sweet to her taste (2.3)}

According to Holman, the erotic connotation is clear (fellatio), especially since the Hebrew word chek (for her palate) is used. ${ }^{25}$ In the allegorical interpretations however, fruit refers to the law, blessings of the word, etc.

The Targum renders:

Just as the citron is beautiful and is praised among ornamental trees and all the world acknowledges it, in the same way the Master of the World was praised among the angels when he revealed himself on Mount Sinai, at the time he gave the Law to His people. At that time, I longed to dwell under the shadow of his Presence, and the commands of his Law were like spice to my palate-and the reward for my observances was stored up on my behalf for the world to come.

21 Luther, Notes on Ecclesiastes, 208.

22 Statenbijbel 1637: 654.

23 Pope 1977: 350-352.

24 Exum, Song of Songs, 98.

25 Holman, "Pleidooi." 
Luther emphasises the feeding aspect of the fruit, which refers to the Word that truly nourishes. He writes:

This is the second blessing from the Apple Tree (the shadow referred to defence - EHS) which he extols here, namely, that not only is the government of a godly people defended by their God but they receive other blessings of every sort from him too. These are great if they are applied to the blessings of the Word, in which true nourishment lies ... ${ }^{26}$

The Statenbijbel (p. 655) interprets the man's fruit as referring to the salvation from Christ which the congregation obtains through Christ, including his death, resurrection and also ascension, as well as the consolations which are sweet to the hearts of the believers. ${ }^{27}$

\section{Faint with love and embraced in the wine-house (2.5-6)}

The Targum renders:

5. And when I heard the voice of His Word that was speaking from within the flame of fire, I trembled and finally shook from fear. Then I approached Moses and Aaron and I told them, 'You receive the voice of YY's words from within the fire. But bring me to the House of Study and sustain me with the words of the Law, upon which the world is based. And put chains upon my neck, explaining the holy words which are sweet to my palate as apples of the Garden of Eden. And I will be occupied with them-perhaps they will heal me, since they have made me lovesick.'

6. While the people of the House of Israel were wandering in the wilderness, four clouds of glory surrounded them from the four winds [i.e., directions] of the earth, so that the Evil Eye had no power over them. Another cloud was above them, so that neither the heat nor the sun, and neither rain nor hail would overcome them. Another was below them, and it carried them as a nursing father carries the infant in his bosom. Another ran before them three days' journey to level mountains and raise valleys; it killed all the poisonous serpents and scorpions in the wilderness; and it would scout out for them a suitable place for them to rest, so that they could be occupied with instruction in the Law which had been given to them by the right hand of YY.

Acknowledging the strength of "young love", for Luther, "sick with love" refers to the whole being that is on fire "with the love of my God out of this consideration of His blessings. ${ }^{28}$ Luther fully acknowledges the erotic nature of

\footnotetext{
26 Luther, Notes on Ecclesiastes.

27 Statenbijbel 1637: 655.

28 Luther, Notes on Ecclesiastes, 216.
} 
the embracing, though within a marital context: 'This too is a figure drawn from the love of bride and groom.' He even adds: 'It is a holy and lawful love, and therefore Satan hates it and tries to impede it even though it is the font of procreation and education. ${ }^{29}$ But then he proceeds to interpret the embrace as that of God: 'He (Solomon) includes two special blessings belonging to this people: the kingdom, or government, which he calls the left hand, and the priesthood, or worship of God' (the right hand implied). ${ }^{30}$

For the Statenbijbel, the phrase "sick with love" refers to the constant longing for Christ's (the groom's) consolations, for God is the healer of the sick. ${ }^{31}$ The embrace refers to the forgiveness of sins and the consolations of the Spirit. The sick head rests on the left hand, the right hands embracing is a sign of love.

\section{Belonging to one another: he pastures amongst the lilies (2.16)}

The Targum's rendering has no erotic connotation, but ironically the opposite, war:

At that time, they turned in repentance. And Moses the prophet stood ready and prayed before YY. Joshua, his servant, was equipped and went forth from beneath the edges of YY's cloud glory, and with him went righteous heroes (who in their deeds resemble the rose). They waged war against Amalek and shattered Amalek and his people under the ban of YY: death and destruction according to the law of the sword.

Interestingly, the Targum gives a different rendering of the same words in 6.2-3:

2. And the Lord of the World received their prayer favourably and went down to Babylon to the Sanhedrin of sages and gave relief to his people and brought them up from their exile by means of Cyrus, Ezra, Nehemiah, Zerubbabel son of Shealtiel, and the Elders of the Jews. And they built the Temple, and appointed the priests over the sacrifices, and the Levites over the guardianship of the Holy Word. And He sent fire from heaven and favourably received the sacrifices and the spice incense. And as a man feeds his beloved son with delicacies, that is how he indulged them. And as a man gathers roses from the plain, so he gathered them from Babylon.

29 Ibid.

30 Ibid.

31 Statenbijbel 1637: 655. 
6. And in that day I worshipped the Lord of the World, my Beloved. And my Beloved made his holy Presence dwell within me and He fed me with delicacies.

For the words "My beloved is mine, and I am his", Luther has no allegorical interpretation. He comments: 'This is the sort of response in which the bride answers the Groom (capital by translator, German in any case). She replies that she wants to do this, to preserve in sincerity and to mark out and capture the foxes. ${ }^{32}$ On the "pasturing among the lilies", he offers no comment. Nor does he in the repetition of this verse in 6.2-3.

The Statenbijbel interprets 16a in terms of Ps. 23 by saying that God is the shepherd and the bride speaking is his flock of sheep that lacks nothing. ${ }^{33}$ God pastures his flock not only on a healthy but a pleasant field full of lilies. The pasture refers to the divine word which is as sweet as honey and the lilies refer the company of saints who are like lilies among thorns. The erotic suggestion of the text is totally overlooked and replace by religious activity.

\section{Founding the beloved and continuously hugging him (3.4)}

The Targum renders:

Then after a little time, YY turned from his fierce anger and he commanded Moses the prophet to make the Tent of the Appointed Time (tabernacle) and the Ark and he caused his Presence to dwell within it. And the people of the House of Israel would offer their sacrifices and were occupied with the words of the Law in the chamber of the House of Study of Moses, their rabbi, and in the classroom of Joshua, son of Nun, his assistant.

According to Luther, the statement is about Solomon under whose rule 'the kingdom enjoyed an abundant flowering of peace and every kind of blessing. ${ }^{34}$ It is not Solomon praising himself but the state that acknowledge the divine blessings of God. The joy of the hugging apparently refers to these divine blessings.

According to the Statenbijbel, finding the man refers to the "fulfilling of the promise of our Lord Jesus Christ'. He is held (or hugged) with the hand of faith. ${ }^{35}$

\footnotetext{
32 Luther, Notes on Ecclesiastes, 222.

33 Statenbijbel 1637: 655.

34 Luther, Notes on Ecclesiastes, 224.

35 Statenbijbel 1637: 655.
} 


\section{Two breasts like fawns feeding among the lilies (4.5)}

The Targum renders:

Your two redeemers who are destined to redeem you, Messiah Son of David and Messiah Son of Ephraim, resemble Moses and Aaron, the sons of Jochebed (who are comparable to two young antelopes, twins of a gazelle). And by their merit they fed the people of the House of Israel for forty years in the wilderness on manna, plump fowl, and the water of Miriam's well.

The text is part of the beauty description of the women of 4.1-7. Luther comments:

In addition to the description of the ministry of the Word he has given through the eyes, the teeth, the hair, and the tower, he now applies it to the image of the breasts, an image which aptly pictures those consolations which are made to terrified minds. As Paul says in 2 Tim. 3.16: 'All Scripture is inspired by God and profitable for teaching, for reproof, for correction, and for training in righteousness. ${ }^{36}$

Where the other bodily parts represent the word in general, the breasts therefore represent the Bible.

The Statenbijbel has two possible references for the breasts: firstly, the teaching of the Old and New Testaments through which the believers are fed; secondly, it could also refer to the ministry of the word and the holy sacraments. Feeding among the lilies refers to the sound doctrine of the church. ${ }^{37}$ The plain erotic sense of the text does not function, and there are two related, but different, allegorical interpretations offered by one author.

\section{Lips distilling nectar, honey and milk under her tongue (4.11)}

The Targum renders:

And when the priests pray in the court of the Sanctuary, their lips drip flowing honey. And your tongue, $\mathrm{O}$ chaste bride, with your utterances - their songs and praises are sweet as milk and honey. And the scent of the garments of the priests is like the scent of frankincense.

The reference to the tongue of the (chaste) bride is one of the few instances that some erotic flavour is retained in the Targum. However, it refers to the scent of the priests' garments.

\footnotetext{
36 Luther, Notes on Ecclesiastes, 230.

37 Statenbijbel 1637: 656.
} 
For Luther body fluids that go along with deep kissing should not be imagined. The honeycomb, for him, refers to a people that has the ministry of the Word. It drips because it spreads in all directions. 'This sweetness and purity of doctrine pervade the entire people'. Milk feeds the sick. 'This is also the function of the Word, for God does not cast away the infirm. ${ }^{38}$

According to the Statenbijbel (p. 657), it is with lips that God is called upon, his word is preached, his name is praised, and the neighbour is built up. Honey and milk under the tongue refers to the sweetness and pleasantness of the speech while "the smell of the clothes" refers to good works.

\section{The channel of her garden is a paradise with spices (4.13-16)}

The Targum renders:

13. And your young men are full of precepts (like pomegranates), and they love their wives and beget children righteous as themselves. And their odour is like the pleasant spices of the Garden of Eden: cypress trees with spikenard plants.

14. Spikenard and saffron, fragrant calamus and cinnamon, with all the woods of frankincense, pure myrrh, eaglewood, with all types of spices.

15. And the waters of Siloah flow gently with the rest of the waters that proceed from Lebanon to water the land of Israel for the sake of those occupied with the words of the Law (who are likened to a well of living waters), and by the merit of the oblation of water poured on the altar of the Temple that is built in Jerusalem (which is called Lebanon).

16. And on the northern side was a table and on it were twelve loaves of show-bread; on the southern side was the candlestick to give light; and on the altar the priests offered the sacrifice and on it sent up the spice incense.

The Assembly of Israel said, 'Let God, my Beloved, enter the Temple and favourably receive the sacrifices of his people.'

For Luther, the women as sealed garden refers to the people 'regulated by circumcision and other rites ... sealed by promises'. The paradise is full of trees which are saintly men. The fruits refer to the 'good teachers, magistrates, heads of families, servants and servant girls. ${ }^{39}$ The spices are those praying, and "myrrh and aloes" quite ironically signify those who mortify the flesh. The

38 Luther, Notes on Ecclesiastes, 234.

39 Luther, Notes on Ecclesiastes, 235. 
garden fountain is Jerusalem. The erotic connotation is not even considered; the opposite is read into the text.

According to the Statenbijbel, the fountain refers to the fountain from which the holy gospel streams which strengthen the grieved hearts. ${ }^{40}$ The paradise of spices refers to good works of the churches.

\section{Eating honeycomb and drinking wine and milk in the garden (5.1)}

The Targum renders:

Then the Holy One, blessed be he, said to his people, the House of Israel: 'I have come into my Temple which you built for me, O my Sister, Assembly of Israel (who are comparable to a chaste bride). I have caused my Presence to dwell among you. And I have favourably received your spice incense which you performed for my name. I have sent fire from heaven and it devoured the burnt offerings and the holy sacrifices. The libations of red wine and white wine, which the priests poured out on my altar, was favourably received. Now come, O priests who love my precepts, and eat what is left of the offerings and delight yourselves with the bounty made ready for you.'

Not noticing, or perhaps avoiding, the erotic implications of the man enjoying with his mouth the delicacies of the women's body (oral sex in plain words), Luther again states that 'myrrh is the mortification of the flesh'. For him, the spice refers to good works which God enjoys. The "my" in "my honeycomb" is emphasised and refers to the assemblies, works, speaking and teaching that please God. The call on friends to become drunk with love is an exhortation to the churches to enjoy her benefits and gifts with gratitude. ${ }^{41}$

According to the Statenbijbel, the garden is the congregation. God enjoys the honeycomb, wine and milk, referring to the word of God, the doctrine and the holy sacraments. ${ }^{42}$ Being drunk with love refers to love towards one another or spiritual joy that lasts into eternity.

\section{Thrusting his hand in the opening, she yearns for him (5.4-5)}

According to a note in the New Catholic Bible of the Catholic Truth Society ${ }^{43}$, 'the imagery of v. 4-5 is sexually unmistakable, but the sudden disappearance is dreamlike, and the watchmen may symbolize the custodians of propriety'.

\footnotetext{
$40 \quad$ Statenbijbel 1637: 657-658.

41 Luther, Notes on Ecclesiastes, 237

42 Statenbijbel 1637: 658

$43 \quad$ Catholic Truth Society 2007: 1117.
} 
The Targum renders:

4. When it was made clear before YY that the people of the House of Israel were not willing to repent and return to him, he stretched forth his mighty blow against the tribe of Reuben and Gad and the halftribe of Manasseh on the other side of the Jordan and delivered them into the hand of Sennacherib, King of Assyria, and he exiled them to Lahlahand Habor, rivers of Gozan, and to the cities of Media. And he took from their hand the molten calf which sinful Jeroboam had put in Leshem Dan, which is called Pamios, in the days of Peqah, son of Remaliah. When I heard, my compassion was stirred for them.

5. When the mighty stroke of YY came down hard on me, I regretted my actions and the priests brought the sacrifice and offered up spice incense but it was not received favourably, because the Lord of the World had shut the doors of repentance in my face.

Ironically again, there is no trace of eroticism left in Luther's reading. He comments: 'God thrusts His hand through the latch opening ... when he sent the Assyrians and when he pressed the people with other calamities ... He aroused the government.' ${ }^{44}$ Her yearning, and that 'her hands that dripped with myrrh and her fingers with liquid myrrh', according to him, indicates how difficult is for her (the people) to conquer the flesh giving her assent to God

According to the Statenbijbel, the man's hand in the door opening refers to Christ opening the door of the heart through continuous preaching and admonition, and thereby invoking a burning love and longing. ${ }^{45}$ 'Her hands and fingers dripping myrrh' refers to the remorse and repentance of the faithful.

\section{His cheeks yielding fragrance, his lips liquid myrrh (5.13)}

Not only can the women be beautiful or sexy, but also the man as seen in the wasf of 5.10-16. Verse 13 is probably its most erotic part.

The Targum renders:

The two stone tablets which he gave to his people were written in ten lines (resembling the lines of the spice garden), multiplying subtleties and reasons as the garden multiplies spices; and the lips of his sages who are occupied with the Law distil reasons on every side and the word of their mouth is like choice myrrh.

Interestingly, if Luther were consistent in his interpretation, the cheeks and lips would have to refer to God's lips and cheeks. However, he interprets them also as belonging to the people and thus the women. According to Luther,

44 Luther, Notes on Ecclesiastes, 238.

45 Statenbijbel 1637: 658. 
the 'cheeks are the whole people's external manner of life, which flows from the Word; it is more vigorous, it yields a sweet fragrance of peace, humility, faith etc. ... The lips are sweet and full of love; yet they distil myrrh, that is mortifying doctrine. They teach, accuse, persist, reprove'.

According to the Statenbijbel, the cheeks and lips yielding fragrance and myrrh refers to the pleasant grace of Christ which the faithful receives. ${ }^{46}$ It consoles and revitalises. Unlike Luther it indeed here comes from the man's lips and cheeks.

\section{The most erotic part? The vulva as rounded bowl (krater) encircled with lilies (7.3 Heb.)}

The explicit eroticism of 7.3 (and how even translations avoid it by words like "navel or belly") was argued by Loader ${ }^{47}$ and need not be repeated here.

The Targum renders:

7.3 [2]. The head of your council, by whose merit the whole world is sustained (as a foetus is sustained by the navel in the womb of its mother) was as bright with [knowledge of] the Law as the disk of the moon, when he goes forth to declare pure or impure, innocent or guilty. The words of the Law are never lacking in his mouth, just as the water of the great river that emerged from Eden never fails. And seventy sages surrounded him like a round threshing floor. And their storehouses were full of the holy tithes, the vow offerings, and the free-will offerings that Ezra the priest, Zerubbabel, Joshua, Nehemiah and Mordecai Bilshan, the men of the Great Synagogue (who resembled roses) had fenced off for their use, in order to enable them to be occupied with the Law day and night.

The terms for navel and womb are retained, but in the end refer to the Torah that sustains the world.

Interestingly enough, although Luther also uses the words navel and belly, and his interpretation still refers to the people, he retains much about procreation. He comments:

The power of conception and generation is in the navel. They maintain this view from Job 40.16: "His power is in the navel of his belly". But He means parents and teachers of the young. They are like a bowl which is never empty of wine, that is, their instruction is not worthless ... [regarding the belly] your instruction and learning are fruitful like a heap of wheat. Roundness is praised in

$46 \quad$ Statenbijbel 1637: 659.

47 J. A. Loader, "Exegetical erotica to Canticles 7:2-6," Journal for Semitics, 10 (2001): 98-111. See also the discussion with archaeological material in Keel, The Song of Songs, 234. 
the belly, as is a deeper navel set a little into the belly. Roses [referring to the lilies] is his name for Scripture and the laws. ${ }^{48}$

The Statenbijbel also uses the translation "navel" and "belly". Regarding the navel, it comments:

The navel is the part of the belly through which the child is fed while being in the mother's body. It must be understood as the navel of being born again, through which the faithful receive spiritual life when they are received into the stomach of the church through the seed of the divine word. It is compared to a cup which lacks no drink ... since being born again ... never departs from the elect. ${ }^{49}$

The belly surrounded by lilies refers to the abundance of fruits which the church has which crowns it with the blessings of God and spiritual joy.

None of the three renderings even considers the possibility that the genitalia of the women (not even to mention their being in a state of excitement) are referred to.

\section{Desiring to climb the palm tree - grabbing the breasts and kissing her (7.8-10 Heb.)}

The cycle in chapter 7 moves from observation (7.1-6), to expressing of desire for sexual interaction (7.8-10), and finally consummation 7.13.

The Targum renders:

7.8 [7]. [How beautiful you are] at the time the priests spread their hands in prayer and recite the blessing on their siblings of the house of Israel, the fingers of their hands stretch out like the branches of a palm tree, their stature is like a date tree, and your congregations stand facing the priests, their faces bent to the ground like a cluster of grapes.

7.9 [8] YY said by his Word, 'I will go and test Daniel and see whether he will be able to stand this trial, as Abraham (who resembled a palm branch) stood in ten trials. And I will also test Hananiah, Mishael, and Azariah, whether they are able to stand in their trials. Because of their merit, I will redeem the people of the House of Israel (who are comparable to a cluster of grapes). And the fame of Daniel, Hananiah, Mishael, and Azariah will be heard in all the earth and their fragrance will spread like the fragrance of the apples of the Garden of Eden.'

48 Luther, Notes on Ecclesiastes, 250.

49 Statenbijbel 1637: 661. 
7.10 [9] Daniel and his companions said, 'We will take upon ourselves the decree of the Word of YY, as Abraham our father (who was like old wine) took it upon himself. And we will walk in paths that are proper in his sight, just as the prophets Elijah and Elisha walked, by whose merits the dead rose like a man who slumbers; or like Ezekiel, the son of Buzi the priest, by the prophecy of whose mouth the sleeping dead were awakened in the valley of Dura.'

The Targum's application to the book Daniel probably derives from the Sifra in Lev. 18.5. "Your eyes are stately as a palm tree," refers to Hananiah, Mishael, and Azariah, who stood upright like palm trees rather than bow down to Nebuchadnezzar's image (Daniel 3) ${ }^{50}$.

For Luther, the palm tree refers to the people who, because of their priests and officials, do not bend under heavy weight. The desire to climb the tree refers to God's willingness to embrace Solomon's kingdom. The breasts refer to teaching. The kisses (throat) are directed to God and please God. The lips refer to the reporting and spreading "the great knowledge of histories". There are no traces left of the man's desire for sexual contact. ${ }^{51}$

According to the Statenbijbel, the palm tree is a beautiful upright tree which is always green and always bears good fruit. ${ }^{52}$ Therefore, the holy state (of believers) is compared with it. The man's desire to grab the breasts (branches) refers to his taking them to purify and preserve them so that they can bear even better fruit which consists in the knowledge of Christ. Noteworthy is the "purification" of the breasts in order to produce spiritual fruit.

\section{Giving him her love in the vineyards (7.13)}

The desire for sexual interaction finds its consummation in $7.13 \mathrm{c}$ when the women says sham eten et dodai lach ('there I will give you my love(caresses)').

The Targum renders:

7.13 [12]. The Children of Israel said one to the other, 'Let us get up early in the morning and go to the Synagogue and to the House of Study (school) and search in the Books of the Law and let us see whether the time of Redemption has come for the people of the House of Israel (who are likened to the vine) to be redeemed from their Exile. Let us ask the sages whether the merit of the righteous (who are full of precepts like the pomegranate) is revealed before the Lord, and whether the appointed time has come to go up to Jerusalem, in order

\footnotetext{
50 See Targum to Song of Songs 2018: note 27.

51 Luther, Notes on Ecclesiastes, 251.

52 Statenbijbel 1637: 661.
} 
to give praise there to the God of Heaven, and to bring burnt offerings and holy oblations.'

For Luther, going into the fields refers to Solomon's extended kingdom (including Edom, Palestine, Syria, Moab). Exploring the vineyards represents a search for good, useful men to the state amongst these peoples. Luther translates dodai (love) as breasts and comments: 'We will teach in those regions (referred to earlier) also; we shall put our worship and law into practice even among them. ${ }^{53}$

A well-meant missionary perspective, but nothing about the consummation of love between a man and a woman.

According to the Statenbijbel, the vineyards refer to the churches where the gospel is preached. There in the assemblies of the saints the believers will offer their body as a pleasant sacrifice. The dodai, translated as our outstanding love ("uitnemende liefde"), refers to the enjoyment of the fruit of faith, confessions, gratitude and good works. ${ }^{54}$

\section{Desiring to unashamedly kiss in public (8.1)}

The Targum renders:

8.1. At that time when King Messiah is revealed to the Congregation of Israel, they will say to Him, 'Come, be as a brother to us and let us go up to Jerusalem, and let us suck with you the judgments of the Law, just as a suckling sucks at his mother's breast. All the time that I was taken away outside my land, as long as I was mindful of the Name of the Great God and gave up my life for his Divinity, even the nations of the earth would not scorn me.'

For Luther, the mother's breast actually refers to God, to be 'introduced to all peoples'. To kiss is 'to give the Word, to possess the Gospel'. When it spreads, the "contemptible" people will no longer be despised, for in every kingdom God will be worshipped. There are no traces left of the girls desire to unashamedly kiss in public. ${ }^{55}$

According to the Statenbijbel, the longing refers to the longing that saints will openly experience the day when Christ becomes their brother in the flesh. Him sucking his mother's breasts refer to the saints' enjoyment of the OT and NT. Kissing refers to a manifestation of love which also consists in honour and obedience. $^{56}$

53 Luther, Notes on Ecclesiastes, 253.

54 Statenbijbel 1637: 661.

55 Luther, Notes on Ecclesiastes, 254.

56 Statenbijbel 1637: 662. 
754 Scheffler, “Allegorising Song of Songs," OTE 31/3 (2018): 737-758

18. Giving her juice and being embraced in her mother's house (8.2-3)

The Targum renders:

8.2. 'I will lead you, O King, and bring you up to my Temple. And you will teach me to fear before YY and to walk in his ways. And there we will partake of the feast of Leviathan and will drink old wine preserved in its grape since the day the world was created and from the pomegranates and fruits prepared for the righteous in the Garden of Eden.'

8.3. The Assembly of Israel will say, 'I am the chosen of all nations. I bind tefillin on my left hand and on my head and fix the mezuzah to the right side of my door a third of the height from the lintel so that no demon has power to harm me.'

For Luther, the spiced wine refers to the 'richer and more effective doctrine than there ever was under the Law' which the people will approve. The juice of the pomegranates 'perhaps' (according to Luther) refers to 'the new character of the doctrine from the various testimonies of the prophets. ${ }^{\text {'57 As far }}$ as the embracing with the left and right hand, he recognises the plain sense of the text: 'Here he uses yet another image from the marriage embrace. By this image, he indicates that this kingdom is in God's protection, and is ruled and directed by God. ${ }^{58}$ We thus here have a case of allegorical interpretation without denying the erotic sense (though within the confines of marriage).

According to the Statenbijbel, giving from her wine and juice of pomegranates to drink refers to the fruits the church brings to the honour of Christ and which are pleasant. ${ }^{59}$

\section{Love as strong as death, erotic passion as fierce as the sheol, a divine flame (8.6)}

The Targum renders:

8.6. The Children of Israel on that day will say to their Lord, 'We beseech you, set us as the seal of a ring on your heart, as the seal of a ring on your arm, so that we may never again be exiled. For the love of your Divinity is as strong as death, and the jealousy which the nations harbour against us is as powerful as Gehinnom. The enmity which they harbour against us is like the coals of the fire of Gehinnom which YY created on the second day of the Creation of the World to burn the idolators with it.'

57 Luther, Notes on Ecclesiastes, 255.

58 Ibid.

59 Statenbijbel 1637: 662. 
Remarkably shehelbetja where, the divine name (jah) probably features, is not interpreted.

For Luther, the expression about love and jealousy makes sense because it refers to spiritual life. It prompts the faithful to hold on to a "strong love" amidst the trials of life. Marital love and juvenile mindless passion is recognised by him and he even quotes Vergil's amor vincit omnia. He translates qinah as jealousy or envy which is negative, a fury of love, which is like the grave which even prayers won't move. Love is a flame of God, and Gods fire is eternal and inextinguishable. There is consolation in that: the onslaughts of the world, nor Satan can put it out, for love yields to no one, and everything yields to love. Although erotic love is not denied, divine love ultimately receives the focus. ${ }^{60}$

According to the Statenbijbel, love refers here to the spiritual love that mutually exists between Christ and the elect. Even death cannot extinguish it. The qinah (envy), contrary to Luther, emphasises its strength because it consumes and destroys the grave. It is a flame lighted by the Lord - referring to the love of the Spirit of Christ which exists inextinguishably in the life of the elect. ${ }^{61}$

\section{Breasts like towers that bring peace (8.10)}

Defying her brothers that think she is unripe, the women unashamedly praises her breasts that are mature and bring peace.

The Targum renders:

8.10. The Assembly of Israel answers and says, 'I am as strong as a wall in the words of the Law and my children are as sturdy as a tower.' And in that time the Assembly of Israel will find favour in the eyes of her Lord and earth's inhabitants will seek her welfare.

Luther's interpretation once again retains the plain sense and as well as the allegorical one. He comments:

This is the voice of the bride already in her maturity. For after the giving of the Holy Spirit and the revelation of the Word, the church truly has a wall against the cunning of Satan and the heretics. And it has breasts, firm like towers, by which it teaches, consoles, corrects $\ldots$ there of necessity follow peace and tranquillity. ${ }^{62}$

According to the Statenbijbel, the tower-like breasts refer to the service of the church that is established in the believer, adequate to educate Christ's children, feeding them with the word. We are all enemies of God because of our

60 Luther, Notes on Ecclesiastes, 257-258.

61 Statenbijbel 1637: 662.

62 Luther, Notes on Ecclesiastes, 261. 
corruption, but through faith are justified and therefore have peace with God through the Lord Jesus Christ. ${ }^{63}$

\section{CONCLUSION}

Three points can be made in conclusion. First, if one compares the Jewish, Lutheran and the Calvinistic allegorical interpretations (not to deny that there are many more) one finds differences on a macro as well as on a micro level. The unity in interpretation claimed by the allegorical method can be summarised only in one sentence: Song of Songs is about God and his people. But the opinions differ on who God is and who the people is or are. And if one follows the exegesis passage by passage and word by word, the differences proliferate. There can be only one reason for this, and that is that the allegorical method is not exegesis at all, but interpretation. It is a reading into the texts of preconceived ideas about God and humans, which are based on the rest of the Bible or whatever. Therefore, Jewish and Christian allegorical interpretations differ in accordance with these religions. Even further: the allegorical interpretations would even differ according to the different individual interpreters, as we can observe the differences between Luther, the commentator of the Statenbijbel and the neoallegorical interpreter Schwienhorst-Schönenberger ${ }^{64}$. Allegorical interpretation constitutes no exegesis of the text, not even interpretation, but it is application and appropriation.

It is further noteworthy that any allegorical interpretation surfaces only when religion is involved, and a message is to be obtained from the text by the translator or interpreter. Secular interpreters seem to have no need for allegory.

A final point is that allegorical appropriations can be and usually are very creative, creating new religious texts as it were. As such, it should be appreciated and understood in its own right. Luther's politics is reflected in his commentary on Song of Songs and in the Statenbijbel's exposition, we find a compendium of $17^{\text {th }}$ century orthodox Calvinistic theology. In Schwienhorst-Schönenberger's neo-allegorical reading, his theological views are also reflected, as well as his views about the history of ancient Israel. If we keep apart what belongs apart, the question of allegorical exegesis can be dealt with. It presents no exegesis of the text but can be interpreted and even appreciated as expressions of the allegorical interpreter's own theology or thinking.

\section{BIBLIOGRAPHY}

Carr, D. The erotic word: Sexuality, Spirituality and the Bible. Oxford: Oxford University Press, 2003.

63 Statenbijbel 1637: 663.

64 Schwienhorst-Schönenberger, Das Hohelied. 
Catholic Truth Society. The CTS New Catholic Bible. London: The Incorporated Catholic Truth Society, 2007.

Exum, J.C. Song of Songs: A Commentary (OTL: London: SCM. 2005).

Fischer, S. Das Hohelied Salomos zwischen Poesie und Erzählung. Tübingen: Mohr Siebeck. 2010. https://doi.org/10.1628/978-3-16-151113-4

Gerleman, G. Ruth, Das Hohelied (Neukirchen: Neukirchener Verlag. 1965).

Holman, Jan. 1997. 'Pleidooi voor een onderaards Hooglied: Resultaten van een cultureel-antropologische lazing.' Tijdschrift voor Theologie 37:113-131.

Keel, O.The Song of Songs: a continental commentary. Transated by F.J. Gaiser. Minneapolis: Fortress Press, 1994.

Küng, H. 1994. Grosse christliche Denker München: Piper Verlag).

Lamparter, H. Das Buch der Sehnsucht: Ruth, Hoheslied, Klagelieder. Stuttgart: Calwer Verlag 1962.

Landy, F. Paradoxes of paradise: Identity and difference in the Song of Songs. 2nd ed.; Sheffield: Sheffield Phoenix Press, 2011.

Loader, J A. 2001. 'Exegetical erotica to Canticles 7:2-6', Journalfor Semitics, 10: 98111.

Luther, Martin. [1539] 1972 Notes on Ecclesiastes. Lectures on the Song of Solomon. Treatise on the last words of David. Edited by Jaroslav Pelikan. Luther's Works Vol. 15; Saint Louis: Concordia Publishing.

Melamed, Raphael Hai. 1919-1922. 'The Targum to Canticles According to Six Yemen Mss. Compared with the "Textus Receptus" (Ed. de Lagarde)', Jewish Quarterly Review, New Series, 10 (1919-20): 377-410, 11 (1920-21): 1-20, and 12 (192122): 57-117.

Müller, H.-P. "Das Hohelied." Pages 1-90 in Das Hohelied/Klagelieder/Das Buch Ester. Edited by H.-P. Müller, O. Kaiser, \& J.A. Loader. 4th ed. ATD 16/2. Göttingen: Vandenhoeck \& Ruprecht 1992.

Pope, Marvin H. Song of Songs: A New Translation and Commentary. The Anchor Bible 7C. New York: Doubleday \& Company, 1977.

Ringgren, H.. 'Das Hohelied.' Pages 253-292 in Das Hohelied/Klagelieder/Das Buch Ester. Edited by Ringgren, H. \& Kaiser, O. 3rd edition ATD 16/2. Göttingen: Vandenhoeck \& Ruprecht, 1981.

Rudolph, W. Das Buch Ruth, Das Hohelied, Die Klagelieder. KAT 17. Gütersloh: Gerd Mohn, 1962.

Schwienhorst-Schönenberger, L. Das Hohelied der Liebe. Freiburg: Herder, 2015.

Statenbijbel. 1637.

Staten-Generaal van de Vereenigde Nederlande

1673. Bijbel, dat is de gansche Heilige Schrift bevattende al de canonieke boeken des Ouden en Nieuwen Testaments (Anoniem: Statenbijbel). Leiden: A.W. Sijthoff.

Targum to Song of Songs. 2018. Trans. J.C. Treat. Assessed on 21 July 2018; https://www.sas.upenn.edu jtreat/song/targum/

Zenger, E. et al. (eds.). Einleitung in das Alte Testament. 3rd ed. Stuttgart: Kohlhammer, 1998.

Einleitung in das Alte Testament. 9th updated ed.; Stuttgart: Kohlhammer, 2016). 
758 Scheffler, “Allegorising Song of Songs," OTE 31/3 (2018): 737-758

Prof Eben Scheffler, Department of Biblical and Ancient Studies, University of South Africa. Email: schefeh@gmail.com. 